\title{
Steroid- Induced Hyperglycemia: A Review
}

\author{
Nasir A. M AL-Jurayyan¹, Abdulrahman N.A AL- Jurayyan², Sharifah D.A. Al Issa ${ }^{3}$ \\ 1Professor and Senior Pediatric Endocrinologist, ${ }^{2}$ Medical Student, ${ }^{3}$ Consultant Pediatric Endocrinologist, \\ College of Medicine, King Saud University, Riyadh, Saudi Arabia.
}

\section{ABSTRACT}

Steroids are medications that have been used extensively in a variety of medical conditions due to their anti inflammatory and immunosuppressive properties, Glucocorticoids have several side effects, with hyperglycemia being one of the most common.

In this brief review, we discuss the steroid-induced hyperglycemia diagnoses, epidemiology, pathophysiology as well as the pharmacokinetics and pharmacodynamics associated with steroid use Strategy for the treatment was also highlighted.

Key words: Steroid- induced, Diagnoses, Hyperglycemia, Pathophysiology, Treatment.

\section{INTRODUCTION}

Steroids are the main cause of drug induced hyperglycemia. Since its discovery in 1940, glucocorticoids have become as one of the most widely used and effective treatment for various inflammatory and autoimmune disorders. They are also used as replacement therapy in adrenal insufficiency either at physiological as well as in supra physiological doses for the management of various disorders. Despite their beneficial effects long-term systemic, oral or parenteral, use are associated with well-known side effects including hyperglycemia. ${ }^{1-6}$

In this brief review, we discuss the clinical diagnoses, epidemiology, the pathophysiology of glucocorticoid-induced hyperglycemia as well as the pharmacokinetics and pharmacodynamics associated with steroid use and outline. A strategy for the treatment was also highlighted.

\section{DIAGNOSIS}

All patients who are started on steroid therapy should have a base line serum glucose level. Daily monitoring of glucose should be started if blood sugar exceeds $11 \mathrm{mmol} / \mathrm{L}$. The diagnosis of steroid induced hyperglycemia is similar to the current criteria established by the American- Association of Diabetes. ${ }^{7}$

Based on the pathophysiology and pattern of steroid-induced hyperglycemia it seems that some of the current criteria for diagnosis underestimate its diagnoses. Hb/AIC determination or postprandial glucose determination are the best screening test for the long term therapy. ${ }^{8}$

Several protocols to detect patients at risk of developing steroid induced hyperglycemia based on the hypothesis that

\section{${ }^{*}$ Correspondence to:}

Nasir A. M. Al -Jurayyan

Department of Pediatrics (39),

College of Medicine and King Khalid University Hospital,

King Saud University,

Riyadh, Saudi Arabia.

\section{Article History:}

Received: 06-11-2016, Revised: 14-11-2016, Accepted: 29-11-2016

\begin{tabular}{|l|c|}
\hline \multicolumn{2}{|c|}{ Access this article online } \\
\hline $\begin{array}{l}\text { Website: } \\
\text { www.ijmrp.com }\end{array}$ & Quick Response code \\
\hline DOI: & \\
10.21276/ijmrp.2016.2.6.027 & \\
\hline
\end{tabular}

abnormalities in insulin secretion and function and loss of the beta cell function exist. An individual can be exacerbated in response to an increase in insulin requirements secondary to steroid use. It was shown recently that the use of "stress test", in which the administration of $8 \mathrm{mg}$ dexamethasone provides timely detection of increases in serum glucose, $C$ peptide and insulin in at risk population, whereby one can predict this complication prior to the usual dose of the steroid. ${ }^{9}$

\section{INCIDENCE}

The incidence of steroid induced hyperglycemia in hospital setting, indicated that more than half of these patients receiving high dose of steroids developed hyperglycemia, with an incidence of $86 \%$ of at least one episode of hyperglycemia and $48 \%$ of patient presenting a mean blood glucose $\geq 7.8 \mathrm{mmol} / \mathrm{L}(140 \mathrm{mg} / \mathrm{dl})$. The main associated factors related to in patient hyperglycemia are previous history of diabetes mellitus, a higher prevalence of comorbidities, prolonged treatment with steroids and older age. Also, there are population with a greater risk of developing hyperglycemia during treatment such as those with concomitant use of mycophenolate mofetil, and calcineurin inhibitors. Abnormal fasting glucose and impaired glucose tolerance test were also factors.

In a retrospective study of non-diabetic patients with primary renal disease treated with prednisolone of $0.75 \mathrm{mg} / \mathrm{kg}$ daily, $47 \%$ were found to have 2- hour post lunch plasma glucose values exceeding $11.1 \mathrm{mmol} / \mathrm{L}(200 \mathrm{mg} / \mathrm{dl})$, but normal fasting glucose value. . $-6,10-13^{-13}$ 


\section{PATHOPHYSIOLOGY}

The predominant mechanism responsible for glucose intolerance after steroid therapy is reduced insulin sensitivity (table) which can be up to $60-80 \%$ depending on the dose and the type of steroid used. Similar to that in type 2 diabetes mellitus. Studies showed that increased insulin resistance occurs in the liver, resulting in increased basal glucose production and the peripheral where glucose used is impaired.

Insulin stimulates peripheral glucose uptake through binding to its receptors, stimulating glucose transport 4 (GLUT 4 ) to the cell surface and activating a signaling cascade that promotes the use of glucose within the cell including glycogen synthesize, by interfering with this signaling cascade, glucocorticoids impair glucose use through post receptor defects, such as diminished GLUT4 expression and migration and decreased glycogen synthesis. Glucocorticoids also increase insulin resistance in the liver by enhancing hepatic gluconeogenesis. ${ }^{1,5,14}$

In addition to insulin resistance, inflammatory disease status may induce beta cell dysfunction through indirect mechanisms. ${ }^{1}$

Table 1: Pathophysiology of steroid - induced hyperglycemia.

Increase in insulin resistance with increased glucose production and inhibition of the production and
secretion of insulin by pancreatic $\beta$-cells
Corticosteroids increase endogenous glucose production, increment in gluconeogenesis and antagonizing the
metabolic actions of insulin
Enhance the effects of other counterregulatory hormones, such as glucagon and epinephrine, which increase
the endogenous synthesis of glucose
Also been shown that the expression of the nuclear receptor peroxisome proliferator-activated receptor a is
necessary for the increment in endogenous glucose production induced by corticosteroids
Corticosteroids reduce peripheral glucose uptake at the level of the muscle and adipose tissue
Costicosteroids also inhibit the production and secretion of insulin from pancreatic $\beta$-cells and induce $\beta$-cell
failure indirectly by lipotoxicity

Figure 1: Management of steroid - induced hyperglycemia.

\begin{tabular}{|c|c|c|}
\hline \multicolumn{3}{|c|}{ Glucocorticoid-induced Hyperglycaemia } \\
\hline \multicolumn{3}{|c|}{ Random Blood Glucose } \\
\hline$\underset{<12 \mathrm{mmol} / \mathrm{L}}{\downarrow}$ & $\underset{12-17 \mathrm{mmol} / \mathrm{L}}{\downarrow}$ & $\underset{>17 \mathrm{mmol} / \mathrm{L}}{\downarrow}$ \\
\hline Diet Alone & $\begin{array}{l}\text { Diet } \\
\text { Sulphonylurea (e.g. } \\
\text { Gliclazide } 40 \mathrm{mg} \text { od) }\end{array}$ & $\begin{array}{c}\text { Diet } \\
\text { Insulin }\end{array}$ \\
\hline$\downarrow$ & $\downarrow$ & $\downarrow$ \\
\hline $\begin{array}{l}\text { Pre-lunch blood } \\
\text { glucose }<8 \mathrm{mmol} / \mathrm{L}\end{array}$ & $\begin{array}{c}\text { Pre-lunch blood } \\
\text { glucose }<8 \mathrm{mmol} / \mathrm{L}\end{array}$ & $\begin{array}{c}\text { Titrate insulin to } \\
\text { blood glucose } \\
\text { targets }\end{array}$ \\
\hline Yes $\downarrow$ & Yes & Yes \\
\hline Continue to Monitor & Continue to Monitor & Continue to Monitor \\
\hline
\end{tabular}

\section{PHARMACOKINETICS AND PHARMAIODYNAMICS}

Steroids of adrenal origin are synthesized from cholesterol and their secretion followed a circadian pattern and a pulsatile ultradian rhythm. Normal secretion ranges from 8 to $15 \mathrm{mg} /$ day of which $10 \%$ circulates in free form, the rest is bound to carrier proteins mainly albumin and cortisol binding globulin. The plasma half-life ranges from 80-270 min. depending on the type of glucocorticoids used, with an action in tissue that last for 8-12 h.
They are metabolized in the liver and their conjugated metabolites are excreted mainly by the kidney. ${ }^{15}$

The development of insulin resistance is mainly post prandial and varies depending on the type of steroid used; intermediate acting glucocorticoids which a peak of action 4-6 h. Following their administration; their effect on glucose level is mainly during the afternoon and might without effect on fasting glucose when they 
are administered in a single dose. On the other hand, they cause persistent hyperglycemia when administrated in divided doses. Dexamethasone fits in the long - acting glucocorticoids with a steroid hyperglycemia that lasts for more than $24 \mathrm{~h}$, with a slight decline during an overnight fast. ${ }^{15}$

The effect of steroid is usually transient and reversible. As steroid doses are reduced their effect on endocrine metabolism returns to baseline and drug induced diabetes is expected to resolve.

\section{TREATMENT}

Treatment of the steroid-induced hyperglycemia due to the difference in steroid doses and the scheme used. The approach to hyperglycemia should always be individualized. A careful evaluation of the degree of preexisting glucose intolerance, the patient's clinical condition, the degree of hyperglycemia, the type of doses, and the frequency of administration of the steroid and the mechanism of action, pharmacokinetic and pharmacodynamics of the different hypoglycemic agent must be mode in order to determine the best treatment approach in each patient when selecting the best treatment, The first consideration to make is whether to use oral hypoglycemic drug or insulin (figure). $1,2,4,10$

\section{CONCLUSION}

Steroids have been widely used in a variety of medical conditions. Despite their medical efficacy, steroid induced hyperglycemia remains a potentially harmful. A proper understanding of the mechanisms involved in is needed, to allow early detection and effective treatment. Appropriate guideline for the diagnosis and treatment should be established. An individualized approach for the management must be undertaken.

\section{ACKNOWLEDGEMENT}

The authors would like to thank Miss Hadeel N.A Al Jurayyan for her help in preparing this manuscript.

\section{CONFLICT OF INTEREST}

The authors have no conflict of interest to declare.

\section{REFERENCES}

1. Kwon S, Hermayer KL. Glucocorticoid induced hyperglycemia Am J Med sci 2013, 345(4) 274-277.

2. Inzucchi, SE Management of hyperglycemia in the hospital setting N Eng J Med 2006, 355 (18): 1903 -1912.

3. Singh N, Rieder MJ, Tucker MJ. Mechanics of glucocorticod mediated anti-inflammatory and immunosupprersion action. Paed Perinatal Drug Ther 2004; 6 : 107-115.

4. Liu D, Ahmet A, Ward L krishna moorthy P Mandelcorn EP, Leigh $\mathrm{R}$ et al. A Practical guide to monitoring and management of the conplictisus of systemic controcosteriod therapy Allergy, Asthua and clinical immunology 2013: 9(30); doi = 10.11361710 1492-9-30.
5. Clore NJ, Thurby-Hay L. Glucocorticoid induced hyperglycemia Endocr Praet 2009; 15(5): 469-74.

6. Gonzalez-Gonzaler JG, Mireles - Zavala LG Rodriguez Gutimeriez RR, Gomez- Al, Maguer D, Lavalle -Gonzalez FJ, tamez perez $\mathrm{H}$ et al Hyperglycemia related to high dose glucocuticoid use in critically ill patient. Diabetology and metabolic syndrome 2013, 5(18). Doi: 10. 118611758 - 5996.5.18.

7. American Diabetes Association. Diagnoses and classification of diabetic mellitus. Diabetes care 2010 33: supp 1; S 62-9.

8. EL Ghandour S, Azar S. Incretion based therapy in the management of steroid induced diabetic mellitus; Curr diabetes Rev 2014 10(6): 360-363.

9. Abdelmannan D. Tahboub R, Genuth S, Ismail-Beigi F. Effect of dextamethezone on oral glucose tolerance in healthy adults. Endoer Pract 2010;16: 770 -777.

10. Tamez- Perez HE, Quintanilla floors DL, Rodriguez Gutierrez R Gonzales JG, Tamez-Pena Al steroid hyperglycemia: prevalence early detection and therapeutic recommendations: $A$ narrative review. World J diabetes 2015 6(8) 1073-1081.

11. Fong AC, Cheung NW. The high incidence of steroid induced hyperglycemia in hospital, Diabetes Res Clin Pract 2013; 99: 277280.

12. Kim SY, Yoo CG, Lee CT chung HS kim YW Han, SK et al. Incidence and risk factors of steroid induced diabetes in patients with respiratory disease; J Korean Med Sci 2011, 26(2): 264-267. 13. Donihi AC, Raval D, Saut M Korytkowski MT, De Vitru MA. Prevalence of predictors of corticosteroid related hyperglycemia in hospitalized patients ,Endocr Pract 2006; 12:358 -362.

14. Stumvoll M, Goldstein BJ van Haeften TW Type 2 diabetes: Principles of pathogenesis and therapy Lancet 2005; 365: 133346.

15. Perez A, Jansen - Chaparro S, Saigi I, Bernal-Lopez MR Minambres I, Gomez - Huelgas R. Glucocorticoid- induced hyperglylemia. J Diabets 2014; 6: 9 -20.

\section{Source of Support: Nil.}

\section{Conflict of Interest: None Declared.}

Copyright: (c) the author(s) and publisher. IJMRP is an official publication of Ibn Sina Academy of Medieval Medicine \& Sciences, registered in 2001 under Indian Trusts Act, 1882.

This is an open access article distributed under the terms of the Creative Commons Attribution Non-commercial License, which permits unrestricted non-commercial use, distribution, and reproduction in any medium, provided the original work is properly cited.

Cite this article as: Nasir A. M AL-Jurayyan, Abdulrahman N.A AL- Jurayyan, Sharifah D.A. Al Issa. Steroid- Induced Hyperglycemia: A Review. Int J Med Res Prof. 2016; 2(6):137-39. DOI: 10.21276/ijmrp.2016.2.6.027 